DOI: $10.19195 / 0137-1134.115 .1$

JOLANTA BLICHARZ

ORCID: 0000-0002-4581-8629

Uniwersytet Wrocławski

\title{
W KWESTII STOSUNKÓW ZACHODZĄCYCH W SFERZE ZEWNĘTRZNEJ I WEWNĄTRZORGANIZACYJNEJ STOWARZYSZEŃ JEDNOSTEK SAMORZĄDU TERYTORIALNEGO
}

\begin{abstract}
Abstrakt: Nie bez znaczenia dla określenia charakteru norm regulujących stosunki wewnątrzorganizacyjne w stowarzyszeniach jednostek samorządu terytorialnego jest regulacja zawarta w art. 29 ust. 1 pkt 2 Prawa o stowarzyszeniach zawężająca możność uchylenia uchwały organu stowarzyszenia (także dotyczącej kształtowania jej składu osobowego), niezgodnej z prawem lub statutem, do działań podejmowanych przez sąd wyłącznie w postępowaniu nieprocesowym na wniosek organu nadzoru lub prokuratora. To oznacza, że ingerencja sądu w działalność stowarzyszenia powinna mieć wyjątkowy charakter i uwzględniać autonomiczny i samorządny charakter danego stowarzyszenia.
\end{abstract}

Słowa kluczowe: stowarzyszenie gmin, jednostka samorządu terytorialnego, samorząd terytorialny, samorząd gminny

W obowiązującym stanie prawnym kwestię zrzeszania się jednostek samorządu terytorialnego reguluje wprost art. 172 Konstytucji RP zawarty w rozdziale VII „Samorząd terytorialny”. Przepis ten w ust. 1 stanowi, że jednostki samorządu terytorialnego mają prawo zrzeszania się, w ust. 2 zaś ustanawia prawo ich przystępowania do międzynarodowych zrzeszeń społeczności lokalnych i regionalnych oraz współpracy ze społecznościami lokalnymi i regionalnymi innych państw. Jakkolwiek samorząd terytorialny ma konstytucyjne prawo do zrzeszania się, to jednak jest ono uregulowane odrębnie od uprawnień obywateli, dla których stosowne unormowania zawarte są w rozdziale II Konstytucji „Wolności, prawa i obowiązki człowieka i obywatela". Z kolei zasady korzystania z prawa, o którym mowa w art. 172 ust. 1 Konstytucji, określają ustawy. Przykładowo w odniesieniu do gmin takim aktem jest niewątpliwie ustawa z dnia 8 marca 1990 roku o samorządzie gminnym ${ }^{1}$. W art. 84 ust. 1 sformułowane zostały cele, dla których gminy mogą tworzyć stowarzyszenia, w tym również z powiatami i województwami.

1 Tekst jedn. Dz.U. z 2016 r. poz. 446 z późn. zm. 
Podstawą współpracy w ramach stowarzyszeń jednostek samorządu terytorialnego są także przepisy ustawy z dnia 5 czerwca 1998 roku o samorządzie powiatowym ${ }^{2}$, ustawy z dnia 5 czerwca 1998 roku o samorządzie województwa ${ }^{3}$ oraz ustawy z dnia 7 kwietnia 1989 roku Prawo o stowarzyszeniach ${ }^{4}$. Wyróżnione akty prawne stwarzają możliwość współpracy w ramach stowarzyszenia jednostek samorządu terytorialnego zarówno tego samego szczebla (na przykład gmin z innymi gminami), jak i jednostek samorządowych różnych szczebli (na przykład gmin z powiatami i województwami). Pod względem formy mogą to być stowarzyszenia jednorodne (lokalne i regionalne) lub mieszane.

Jednostki samorządu terytorialnego zostały również wyposażone w prawo przystępowania do międzynarodowych zrzeszeń społeczności lokalnych i regionalnych oraz współpracy ze społecznościami lokalnymi i regionalnymi innych państw. Zgodnie z ustawą z art. 2 ust. 1 ustawy z dnia 15 września 2000 roku o zasadach przystępowania jednostek samorządu terytorialnego do międzynarodowych zrzeszeń społeczności lokalnych i regionalnych ${ }^{5}$,jednostki samorządu terytorialnego mogą przystępować do zrzeszeń i uczestniczyć w nich w granicach swoich zadań i kompetencji, działając zgodnie z polskim prawem wewnętrznym, polityką zagraniczną państwa i jego międzynarodowymi zobowiązaniami”. Przepisy ustawy określają również sposób, w jaki może dojść do przystąpienia danej jednostki lokalnej do zrzeszenia międzynarodowego.

Problematyka stowarzyszeń jednostek samorządu terytorialnego ma więc różne wymiary, a realizacja przyjętych założeń przebiega na wielu płaszczyznach oraz w różnym zakresie podmiotowym i przedmiotowym. Podobnie jak złożony jest sam problem, tak również zróżnicowane są kwestie prawne - i to zarówno o charakterze ustrojowo-organizacyjnym (chodzi o rodzaje stowarzyszeń komunalnych, ich zadania), jak i materialnoprawnym (chodzi o wybór dziedzin — zakresu spraw i sposobu ich załatwiania przez wyróżnione podmioty). W różnym stopniu znajdują one wyraz w aktach prawnych.

Stojąc na stanowisku, że stowarzyszenia jednostek samorządu terytorialnego stanowią istotny element sektora komunalnego (samorządowe osoby prawne realizujące cele samorządu terytorialnego), należy niewątpliwie podnieść zagadnienie stosunków zachodzących w sferze zewnętrznej między tymi podmiotami a organami nadzorczymi oraz wewnątrzorganizacyjnej (to jest relacji między organami a stowarzyszeniem lub organami a członkami stowarzyszenia), które regulowane są normami zawartymi w aktach organizacyjnych stowarzyszenia (w statucie, uchwałach i postanowieniach władz statutowych).

$\mathrm{Z}$ analizy Prawa o stowarzyszeniach wynika, że tylko przepisy artykułów 6 , $8,11,12,16-17,21-22,25-26,28-32,36-37$ dotyczą sfery zewnętrznej stowa-

\footnotetext{
2 Tekst jedn. Dz.U. 2018 r. poz. 995.

3 Tekst jedn. Dz.U. 2018 r. poz. 913.

4 Tekst jedn. Dz.U. 2017 r. poz. 210.

5 Dz.U. Nr 91, poz. 1009 ze zm.
} 
rzyszeń jednostek samorządu terytorialnego. Przepis art. 10 określa, jakie elementy formalne powinien zawierać statut, bez precyzowania ich treści. Pozostałe wymienione przepisy regulują pewne zagadnienia życia wewnętrznego stowarzyszeń. Dotyczą one kształtowania własnej struktury i stosunków wewnętrznych, pozwalających na zachowanie odrębności organizacyjnej i autonomii zewnętrznej stowarzyszeń. Wkroczenie organów nadzorczych w wewnętrzną sferę działalności stowarzyszeń jednostek samorządu terytorialnego powinno opierać się na konkretnych przepisach prawa. W obowiązującym systemie prawnym możliwość ingerencji organu nadzoru (wojewody właściwego ze względu na siedzibę stowarzyszenia jednostki samorządu terytorialnego) może nastąpić tylko w wyjątkowych przypadkach (art. 26, 28, 29, 30, 31 Prawa o stowarzyszeniach). Dowodzi to, iż nie można mówić o generalnym upoważnieniu organów nadzorczych do rozstrzygania spraw wewnętrznych stowarzyszeń. Samorządność stowarzyszeń zagwarantowana $\mathrm{w}$ przepisach prawa uniemożliwia bezpośrednią ingerencję organu nadzoru w indywidualnej sprawie o charakterze wewnątrzorganizacyjnym za organ stowarzyszenia. Tak więc organ nadzoru nie może zmienić rozstrzygnięć czy uchwał organów stowarzyszenia, nawet jeżeli są one wyraźnie sprzeczne ze statutem lub prawem. Może natomiast zastosować przewidziane prawem środki nadzoru, na przykład wystąpić o usunięcie istniejących nieprawidłowości w określonym terminie lub udzielić ostrzeżenia władzom stowarzyszenia (art. 28 Prawa o stowarzyszeniach). W toku działalności stowarzyszenia organ nadzorujący ma uprawnienia do: a) dostarczenia przez zarząd, w wyznaczonym terminie, uchwał walnego zebrania członków, b) żądania od władz stowarzyszenia niezbędnych wyjaśnień (art. 25 ust. 2 Prawa o stowarzyszeniach).

Należy jeszcze zwrócić uwagę, że nadzór nad stowarzyszeniami jednostek samorządu terytorialnego ma charakter szczególny. Owa szczególność wynika z tego, że sprawują go zarówno sądy rejestrowe, jak i wojewoda (w przypadku stowarzyszeń osób fizycznych sprawuje go starosta właściwy ze względu na siedzibę stowarzyszenia). Dodajmy przy tym, że w kompetencje do stosowania środków nadzorczych o charakterze władczym ustawodawca wyposażył właśnie sądy. Mogą one na wniosek wojewody (starosty) właściwego ze względu na siedzibę stowarzyszenia lub prokuratora a) udzielić upomnienia władzom stowarzyszenia, b) uchylić niezgodną z prawem lub statutem uchwałę stowarzyszenia lub c) rozwiązać stowarzyszenie, jeżeli jego działalność stanowi rażące lub uporczywe naruszanie prawa albo postanowień statutu i nie ma warunków do przywrócenia działalności zgodnej z prawem lub statutem (art. 39 Prawa o stowarzyszeniach).

Również w fazie rejestracji nowo zakładanego stowarzyszenia jednostek samorządu terytorialnego (także stowarzyszenia osób fizycznych) sąd rejestrowy wydaje postanowienie o jego wpisie do Krajowego Rejestru Sądowego po stwierdzeniu, że statut jest zgodny z przepisami prawa i założyciele spełniają wymagania określone ustawą (art. 16 ust. 1). Jeżeli zaś stowarzyszenie nie spełnia warunków określonych w przepisach prawa, sąd rejestrowy oddala wniosek o jego wpis 
do Krajowego Rejestru Sądowego (art. 16 ust. 3). Znowelizowana ustawa Prawo o stowarzyszeniach nie określa, na czym polega tak zwane niespełnienie przez stowarzyszenie warunków określonych w przepisach prawa, dlatego ocena każdorazowo należy do sądu rozpoznającego sprawę. Wydaje się jednak, że będzie to dotyczyło sytuacji, gdy działalność stowarzyszenia jest sprzeczna z prawem lub statut nie zawiera zapisów, których zamieszczenie jest obligatoryjne. Tak na przykład weryfikacja statutu (w przypadku stowarzyszeń jednostek samorządu terytorialnego) oznacza, że sąd rozpatrzył statut zarówno pod względem celowości istnienia danego podmiotu (zgodności jego celów z przepisami prawa samorządowego), jak i niesprzeczności projektu statutu z prawem o stowarzyszeniach.

Analizując kwestię stosunków zachodzących w sferze zewnętrznej stowarzyszeń jednostek samorządu terytorialnego (to jest między tymi podmiotami a organami nadzorczymi), najogólniej można przyjąć, że mimo istnienia tych samych norm gwarantujących podejmowanie tych samych środków nadzorczych uzależnionych od rodzaju i stopnia stwierdzonych nieprawidłowości w działalności stowarzyszeń jednostek samorządu terytorialnego i stowarzyszeń osób fizycznych (powszechnych) w aktualnej praktyce realizacji uprawnień nadzorczych podstawowe znaczenie ma wybór celu tych podmiotów. W odniesieniu do stowarzyszeń jednostek samorządu terytorialnego cel nie może oznaczać bezwzględnej samodzielności (odrębności) od regulacji przyjętej w prawie samorządowym zarówno na etapie ich tworzenia, w toku działalności, jak i w przypadku zmiany statutu. Wynika to ze szczególnego powiązania tych stowarzyszeń z samorządem terytorialnym. Chodzi zatem o pojęcie stowarzyszenia w znaczeniu ściślejszym w odróżnieniu od pojęcia, które można by określić jako organizację społeczną (pozarządową), samodzielnie stanowiącą o swoich celach.

Dokonując koniecznego uogólnienia, można stwierdzić, że w przypadku istnienia norm równoległych - to znaczy gwarantujących to samo prawo do zrzeszania się osób prawnych zarówno w Prawie o stowarzyszeniach, jak i na przykład w ustawie o samorządzie gminnym - większe znaczenie ma ustawa o samorządzie gminnym. W odniesieniu do norm zawartych tylko w Prawie o stowarzyszeniach nie istnieją jednolite zasady zrzeszania się osób prawnych (na przykład gmin), a więc zasady korzystania z prawa, o którym mowa w art. 172 ust. 1 Konstytucji RP, a które określa sama ustawa o samorządzie gminnym. Ustawodawca zwykły ma pewien zakres swobody w ramach wyznaczonych przez konstytucję $\mathrm{w}$ decydowaniu, jakie cele zamierza osiągnąc za pomocą ustanowionych przez siebie regulacji. Ustawodawca ma wprawdzie nie nieograniczoną, ale daleko idącą swobodę w wyborze i wartościowaniu celów stowarzyszeń jednostek samorządu terytorialnego, co wyraża się zwłaszcza w tym, że decyzja odnośnie do tego, które interesy mają pierwszeństwo, ma charakter polityczny i jest podejmowana przez demokratycznie legitymowaną większość. Ustawodawca ma też swobodę wyboru co do zastosowanych przez siebie środków nadzorczych nad działalnością wyróżnionych stowarzyszeń. Chodzi o to, czy określone podmioty przestrzegają granic ustalonych w normach 
dotyczących ich prawa do zrzeszania się, na przykład służą osiągnięciu założonego w ustawie o samorządzie gminnym celu oraz jego merytorycznemu uzasadnieniu. Z kolei w odniesieniu do norm zawartych w Prawie o stowarzyszeniach daje się zauważyć brak ograniczeń w zakresie formułowania własnych celów przez stowarzyszenie. Można zatem przyjąć, że każde stowarzyszenie może być wpisane do Krajowego Rejestru Sądowego, jeżeli deklarowane w jego statucie cele są zgodne z przepisami prawa. $Z$ tego wynika, że istnieją prawne formy powiązań stowarzyszeń jednostek samorządu terytorialnego w ramach samorządu terytorialnego. Te wzajemne zależności nie są jednak jednolite dla wszystkich podmiotów, które można objąć pojęciem prawnym ,stowarzyszenia”.

Należy jeszcze wskazać na próby ujmowania stosunków zachodzących w sferze wewnątrzorganizacyjnej stowarzyszeń jednostek samorządu terytorialnego. Dyskusje wywołały tu poglądy w kwestii charakteru prawnego norm statutowych regulujących tego typu stosunki. Pierwszy z nich opiera się na założeniu, że normy zawarte w akcie organizacyjnym (statucie) są normami prawnymi, statut zaś rozumiany jest jako akt prawny — źródło prawa przedmiotowego ${ }^{6}$. Drugi traktuje statut stowarzyszenia jako umowę, która zostaje zawarta w momencie zakładania stowarzyszenia (złożenie wzajemnych oświadczeń woli założycieli) ${ }^{7}$. Wyrażany jest też pogląd o statucie jako akcie normatywnym zawierającym normy organizacyjne, określane jako normy społeczne, ustanowione na zasadzie autonomii ${ }^{8}$. Należałoby jeszcze wskazać na próbę innego ujmowania statutu — w momencie tworzenia statut jest umową, natomiast od momentu wpisania do rejestru, czyli od chwili nabycia osobowości prawnej przez stowarzyszenie, staje się aktem normatywnym 9 .

Na tym tle powstaje jednak wiele istotnych problemów prawnych. Zasadniczą kwestią jest pytanie, czy do uznania normy statutowej za normę prawną wystarcza

6 Por. M. Wierzbowski, Akty normatywne organizacji spółdzielczych, Warszawa 1977, s. 57.

7 Zob. szerzej M. Miemiec, Pojęcie statutu w nauce prawa, Wrocław 1975, s. 163. Również w świetle wyroku z dnia 8 kwietnia 2003 roku (IV CKN 39/01, Legalis) SN stwierdził, że statut stowarzyszenia jest umową cywilnoprawną zawieraną pomiędzy stowarzyszeniem a jego członkami, a także między członkami stowarzyszenia. Przystąpienie do stowarzyszenia wiąże się z zawarciem umowy na warunkach określonych w statucie. Sąd Najwyższy wskazał też w uzasadnieniu, że dopuszczalne jest roszczenie odszkodowawcze (na podstawie art. 471 k.c.) w razie naruszenia postanowień statutu stowarzyszenia. Jednocześnie w uchwale z dnia 6 stycznia 2005 roku SN stwierdził, że oświadczenia stron (członków stowarzyszenia i stowarzyszenia) są zrównane w skutkach z oświadczeniami woli w rozumieniu prawa cywilnego. Zarówno przystąpienie do stowarzyszenia, jak i wystąpienie z niego odbywa się na podstawie oświadczenia woli prowadzącego odpowiednio do nawiązania bądź rozwiązania umowy — zob. uchwała SN z dnia 6 stycznia 2005 roku, III CZP 75/04, „Monitor Polski” 2005, nr 3, s. 164.

8 Zob. M. Wach, Status ułomnych osób prawnych w polskim prawie cywilnym, Warszawa 2008, s. 53-54.

9 Por. B. Błażejczak, Lokatorskie prawo do spółdzielczego lokalu mieszkalnego, Poznań 1979, s. 59; oraz L. Stecki, Prawo spółdzielcze, Warszawa 1979, s. 29. W tej kwestii zob. także R. Longchamps de Berier, Studya nad istota osoby prawniczej, Lwów 1911, s. 178.

Przegląd Prawa i Administracji 115, 2018

(C) for this edition by CNS 
sam fakt wyraźnej „aprobaty” tej normy przez właściwy organ lub sąd. Wydaje się, że ranga i treść prawa wymaga szczególnego postępowania prawotwórczego, w którym zespala się kontrolę poprawnego zestawienia treści społecznej z formą prawną ze sposobem jej wyrażania ${ }^{10}$. $Z$ kolei przyjęcie statutu stowarzyszenia jako umowy jest również dyskusyjne, albowiem rodzi możliwość jego zmiany wbrew wyraźnie okazanej woli członka, kiedy głosuje on przeciwko zmianom statutu lub w ogóle na ten temat się nie wypowiada ${ }^{11}$.

Niewątpliwie statuty stowarzyszeń jednostek samorządu terytorialnego stanowią podstawę prawno-instytucjonalną istnienia i funkcjonowania tych podmiotów. Normy statutowe określają cel stowarzyszeń, ich funkcje i ramy instytucjonalno-prawne. W konsekwencji zarówno Konstytucja, jak i ustawy samorządowe, a także prawo o stowarzyszeniach tworzą jedynie pewne zręby związane $\mathrm{z}$ funkcjonowaniem tych podmiotów w Polsce. Natomiast rzeczywiste ich ukształtowanie w ramach danego stowarzyszenia jednostek samorządu terytorialnego dokonywane jest na poziomie jego statutu.

Jakkolwiek ustalenia doktrynalne w kwestii charakteru prawnego statutu mogą mieć niewątpliwie znaczenie praktyczne i odegrać określoną rolę z punktu widzenia mechanizmu tworzenia norm statutowych przez określone podmioty, to jednak nie rozwiązują problemów związanych z charakterem norm regulujących stosunki wewnątrzorganizacyjne w stowarzyszeniach jednostek samorządu terytorialnego (między organami stowarzyszenia a jego członkami). Można powiedzieć, że elementy prawne zrzeszania się jednostek samorządu terytorialnego oraz nadzór nad nimi wynikają z norm powszechnie obowiązujących (ustaw samorządowych i prawa o stowarzyszeniach), cechy organizacyjne zaś z obowiązującego wewnątrz stowarzyszenia statutu. Z punktu widzenia wewnętrznej organizacji stowarzyszenia jednostek samorządu terytorialnego szczególne znaczenie ma tutaj określenie: sposobu nabywania i utraty członkostwa; praw i obowiązków członków; organów stowarzyszenia, w tym organów reprezentujących go na zewnątrz oraz uprawnionych do zaciągania zobowiązań majątkowych; ich kompetencji oraz czasu trwania ich kadencji; trybu dokonywania wyboru organów stowarzyszenia i uzupełniania składów tych organów. Jednocześnie trzeba zaznaczyć, że postanowienia statutu, w tym również odnoszące się do sfery organizacyjnej, muszą znajdować swoje zastosowanie w praktyce funkcjonowania każdego $\mathrm{z}$ tych stowarzyszeń. A zatem jeżeli stowarzyszenie poprzestaje na wpisie do KRS, choć niesprzecznym z prawem statutu, w rzeczywistości opierając swą działalność na innej, niezgodnej z prawem albo postanowieniami statutu, musi się liczyć z zastosowaniem wobec niego środków nadzoru represyjnego, które koncentrują się

10 J. Bafia, Zasady tworzenia prawa, Warszawa 1984, s. 160.

11 Zob. M. Wierzbowski, Rozstrzyganie spraw wynikających z członkowstwa w stowarzyszeniach, PiP 1973, z. 11, s. 65. Także J. Blicharz, Komentarze do ustaw: o zmianie imion i nazwisk, Prawo o stowarzyszeniach, Wrocław 1997, s. 15. 
nie na analizie postanowień aktów normujących jego działalność, lecz na ocenie rzeczywistej działalności.

W celu dokonania ustaleń teoretycznych w kwestii charakteru norm regulujących stosunki wewnątrzorganizacyjne w stowarzyszeniach jednostek samorządu terytorialnego należałoby w pierwszej kolejności podnieść zagadnienie możliwości egzekwowania przyznanych przez statut praw jego członków wobec organów stowarzyszeń. Zasadniczą kwestią jest odpowiedź na pytanie, czy członkowie mogą egzekwować swoje prawa tylko na drodze organizacyjnej, czy przysługuje im także droga sądowa. Przełom w pojmowaniu charakteru członkostwa nastąpił — jak sądzę — przede wszystkim w stanowisku Sądu Najwyższego, wyrażonym w uchwale z dnia 6 stycznia 2005 roku, zgodnie z którym ,roszczenie członka stowarzyszenia o ochronę jego członkostwa przed niezgodnym z prawem lub statutem wykreśleniem ze stowarzyszenia podlega rozpoznaniu na drodze sadowej"12. W orzeczeniu tym SN uznał cywilny charakter członkostwa. Jednocześnie podkreślił, że takie rozwiązanie jest zgodne z Konwencją o ochronie praw człowieka i podstawowych wolności oraz wynikającego z niej prawa do sądu, a także stanowi realizację art. 45 Konstytucji, według którego każdy ma prawo do sprawiedliwego i jawnego rozpatrzenia sprawy bez uzasadnionej zwłoki przez właściwy, niezależny, bezstronny i niezawisły sąd.

Co prawda we wskazanym orzeczeniu SN odniósł się do charakteru członkostwa w stowarzyszeniach powszechnych, niemniej jednak, dopuszczając możliwość zgłoszenia przez członka stowarzyszenia roszczenia o ochronę jego członkostwa na drodze sądowej, w trybie procesowym, uczynił tym samym wyłom co do zasady nieingerowania w działalność stowarzyszenia. Nie kwestionując znaczenia i ważnej roli, jaką odegrało orzecznictwo SN w promowaniu ochrony praw członków stowarzyszenia na drodze sądowej, nie można jednak tracić z pola widzenia faktu, że przyjęcie powyższego stanowiska w jakimś stopniu stanowi zarazem dopuszczenie ingerencji sądów - poprzez brak wyraźnych unormowań szczególnych — w sprawy działalności organizacyjnej stowarzyszeń. Fakt, że ustawa Prawo o stowarzyszeniach nie zawiera delegacji do stosowania odpowiednio przepisów innych ustaw, nie oznacza, że sąd może odpowiednio stosować przepisy innych ustaw regulujących byt, organizację i sposób działania innych osób prawnych (na przykład spółdzielni), choćby były one w swej specyfice bardzo zbliżone do stowarzyszenia. Podobnie przyjęcie, że przedmiotem regulacji wewnątrzorganizacyjnych w stowarzyszeniach są normy prawa administracyjnego, prowadziłoby do uznania spraw wynikających ze stosunku członkostwa za sprawy z zakresu administracji publicznej. Organ nadzoru mógłby wkraczać w sprawy wewnętrzne stowarzyszenia w każdym przypadku naruszenia statutu — na podstawie art. 25 Prawa o stowarzyszeniach.

12 Uchwała z dnia 6 stycznia 2005 roku, III CZP 75/04, Orzecznictwo Sądu Najwyższego, Izba Cywilna 2005, nr 11, poz. 188. 
Nie bez znaczenia dla określenia charakteru norm regulujących stosunki wewnątrzorganizacyjne w stowarzyszeniach jest regulacja zawarta w art. 29 ust. 1 pkt 2 Prawa o stowarzyszeniach, zawężająca możliwość uchylenia uchwały organu stowarzyszenia (także dotyczącej kształtowania jej składu osobowego) — niezgodnej z prawem lub statutem — do działań podejmowanych przez sąd wyłącznie w postępowaniu nieprocesowym na wniosek organu nadzoru lub prokuratora. Oznacza to, że ingerencja sądu w działalność stowarzyszenia (dotyczy to również stowarzyszeń jednostek samorządu terytorialnego) powinna mieć wyjątkowy charakter i uwzględniać autonomiczny oraz samorządny charakter danego stowarzyszenia.

Z tych względów wydaje się celowe, aby przy ustalaniu zakresu uprawnień członków stowarzyszenia odwoływać się do kryterium formalnych powiązań organizacyjnych. Można przy tych ustaleniach odwołać się do przepisów prawnych, które na ogół dość jasno określają, że zarówno przyjmowanie w poczet członków danego stowarzyszenia, jak i pozbawianie członkostwa są kwestiami wewnętrznymi stowarzyszenia, regulowanymi jego prawem wewnętrznym — statutem (art. 10 ust. 1 pkt 4 Prawa o stowarzyszeniach). Gdy statut nie przewiduje wprost możliwości odwołania się przez członka stowarzyszenia od decyzji lub uchwał zarządu lub innego organu stowarzyszenia poza walnym zebraniem członków, to należy domniemywać taką kompetencję walnego zebrania członków z art. 11 ust. 1 Prawa o stowarzyszeniach. Oznacza to, że każda uchwała lub decyzja organów stowarzyszenia może zostać uchylona lub zmieniona przez walne zebranie członków. Zatem członkowie mogą egzekwować swoje prawa przyznane im przez statut (na przykład możliwość zaskarżania uchwał lub decyzji organów stowarzyszenia niższego rzędu) tylko na drodze organizacyjnej.

\section{BIBLIOGRAFIA}

Bafia J., Zasady tworzenia prawa, Warszawa 1984.

Blicharz J., Komentarze do ustaw: o zmianie imion i nazwisk, Prawo o stowarzyszeniach, Wrocław 1997.

Błażejczak B., Lokatorskie prawo do spółdzielczego lokalu mieszkalnego, Poznań 1979.

Czapiński W., Prawo o stowarzyszeniach z komentarzami, Warszawa 1935.

Longchamps de Berier R., Studya nad istota osoby prawniczej, Lwów 1911.

Miemiec M., Pojęcie statutu w nauce prawa, Wrocław 1975.

Stecki L., Prawo spółdzielcze, Warszawa 1979.

Wach M., Status ułomnych osób prawnych w polskim prawie cywilnym, Warszawa 2008.

Wierzbowski M., Rozstrzyganie spraw wynikających z członkowstwa w stowarzyszeniach, PiP 1973, z. 11. 


\section{ON EXTERNAL AND INTERNAL RELATIONS OF ASSOCIATIONS OF SELF-GOVERNMENT UNITS}

\section{Summary}

For determining the legal character of norms regulating internal relations within the associations of self-government units, the important provision is article 29 paragraph 2 item 2 Act on associations. This provision limits the possibility of repealing the resolution of an association's organ (also concerning the members of that organ), which is not in compliance with the law or the statute: repealing can be done by the court only, in non-litigation proceedings, on application of the supervisory organ or the prosecutor. This means the court's interference with the association's activity should have an exceptional character and take into account the autonomous and self-governmental nature of the association in question.

Keywords: association of municipalities, entity of territorial self-government, territorial self-government, municipality self-government 